Kredo 4 (2020)
KREDO: Jurnal Ilmiah Bahasa dan Sastra
Terakreditasi Sinta 4 berdasarkan Keputusan Direktorat
Jenderal Penguatan Riset dan Pengembangan,
Kementerian Riset, Teknologi dan Pendidikan Tinggi
Republik Indonesia
Nomor: 23/E/KPT/2019. 08 Agustus 2019
https://jurnal.umk.ac.id/index.php/kredo/index

\title{
FASHION SEBAGAI KOMUNIKASI: ANALISA SEMIOTIKA ROLAND BARTHES PADA FASHION AGUS HARIMURTI YUDHOYONO (AHY): DALAM PEMILIHAN GUBERNUR JAKARTA
}

\author{
Nabila Myrrha Rahmawati \\ nabilamyrrha@gmail.com
}

Universitas Airlangga, Indonesia

Info Artikel
Sejarah Artikel
Diterima
25 Juni 2020
Disetujui
16 Oktober 2020
Dipublikasikan
28 Oktober 2020

Keywords
Fashion, identity,
Semiotics

Kata Kunci

Fashion, identitas, Semiotika

\section{:}

\begin{abstract}
This study aims to provide readers with insight into the function of fashion as self-identity. Descriptive qualitative approach is used in this study with data analysis in the form of images obtained from the AHY Instagram account. The results of the study showed that in the 2016 Jakarta Governor election, AHY as one of the candidates for Governor used fashion as a medium of political communication in interacting with the people during the campaign period. This can be seen from some clothes that are deliberately chosen to always be worn until the governor election period ends, such as black tacticaal shirts and traditional Jakarta clothing. Political views communicated through fashion are symbols of nationalism and are ready to lead as the identity of a prospective leader which is reflected in the tacticaal shirt he wears. Fashion (clothing) can give an effect on one's physical appearance which can also be used as a communication strategy in attracting support for a particular group of people. This happens because the fashion we wear can give a message or meaning to someone's judgment when interacting.
\end{abstract}

\begin{abstract}
Abstrak
Penelitian ini bertujuan untuk memberi wawasan kepada pembaca tentang fungsi mode sebagai identitas diri. Pendekatan kualitatif deskriptif digunakan dalam penelitian ini dengan analisis data dalam bentuk gambar yang diperoleh dari akun Instagram AHY. Hasil penelitian menunjukkan bahwa dalam pemilihan Gubernur Jakarta 2016, AHY sebagai salah satu kandidat Gubernur menggunakan mode sebagai media komunikasi politik dalam berinteraksi dengan masyarakat selama masa kampanye. Hal tersebut terlihat dari beberapa busana yang sengaja dipilih untuk selalu dikenakan hingga periode pemilihan gubernur berakhir, seperti kaus tacticaal berwarna hitam dan dan busana traditional khas Jakarta. Pandangan politik yang dikomunikasikan melalui mode adalah simbol nasionalisme dan siap memimpin yang merupakan identitas seorang calon pemimpin yang tercermin dalam kemeja tacticaal yang ia kenakan. Mode (pakaian) dapat memberikan efek pada penampilan fisik seseorang yang juga dapat digunakan sebagai strategi komunikasi dalam menarik dukungan untuk kelompok orang tertentu. Ini terjadi karena busana yang kita kenakan bisa memberi pesan atau makna pada penilaian seseorang saat berinteraksi.
\end{abstract}

\section{PENDAHULUAN}

Pemilihan Gubernur atau biasa disebut (PILGUB) menjadi salah satu ajang pesta demokrasi rakyat di Indonesia. Adanya pilgub dimaksudkan agar masyarakat di daerah masingmasing dapat secara langsung menentukan seseorang yang dianggap mampu dan dipercaya rakyat untuk mengemban amanat sebagai pemimpin di daerahnya. Dalam proses pilgub, sosialisasi dan kampanye menjadi hal utama yang selalu dilakukan setalah 216 Jurnal Kredo

Vol. 4 No. 1 Oktober 2020 penetapan beberapa kandidat dari calon dan wakil gubernur. Sosialisasi biasa diselenggarakan dengan menggelar acara peresmian pilgub secara simbolis yang menandakan pesta demokrasi dimulai. Selain itu, dengan diadakanya sosialisasi diharapkan rakyat dan semua pihak terkait dapat memberikan dukungan dan menyukseskan adanya pesta demokrasi

Dalam pesta demokrasi, dijelaskan bahwa setiap rakyat memiliki hak kebebasan dalam menentukan pilihannya. Sebagai warga negara yang memiliki hak suara untuk menjatuhkan 


Kredo 4 (2020)
KREDO: Jurnal Ilmiah Bahasa dan Sastra
Terakreditasi Sinta 4 berdasarkan Keputusan Direktorat
Jenderal Penguatan Riset dan Pengembangan,
Kementerian Riset, Teknologi dan Pendidikan Tinggi
Republik Indonesia
Nomor: 23/E/KPT/2019. 08 Agustus 2019
https://jurnal.umk.ac.id/index.php/kredo/index

pilihan pada calon Gubernur, maka kampanye dianggap penting untuk memperkenalkan dan mempromosikan para kandidat kepada masyarakat. Selama proses kampanye, rakyat disuguhkan produk budaya media online dan offline sebagai sarana untuk mempromosikan para kandidat calon Gubernur. Pada media offline, terpampang poster, spanduk, baliho hingga brosur yang menjadi pemandangan menghiasi setiap sudut kota maupun daerah. Di era digital ini, media sosial seperti instagram, youtube, facebook dan televisi menjadi wadah untuk mempromosikan lebih jauh mengenai visi dan misi, aktifitas yang dilakukan selama kampanye serta konten politik. Segala aktifitas kampanye di rekam dan disebarluaskan melalui media online.

Selama masa kampanye berlangsung, hal yang sering dilakukan oleh para kandidat adalah menyapa rakyat secara langsung dengan mengunjungi daerah-daerah tertentu, khususnya daerah yang dianggap masih butuh banyak perhatian. Tidak hanya itu, di era millenial ini, terkadang para kandidat melakukan pendekatan kepada anak muda dengan bergabung bersama aktifitas mereka. Selama proses pilgub berlangsung, fashion menjadi salah satu sorotan yang menjadi perhatian untuk dibahas, dalam hal ini adalah busana yang dikenakan oleh para kandidat. Busana yang dikenakan menjadi ciri khas tersendiri bagi setiap kandidat sehingga dapat menjadi suatu media komunikasi.

Fashion mulai berkembang di era modernitas seiring dengan munculnya kapitalisme industri. Pernyataan tersebut sama seperti yang dungkapkan oleh (Wilson\&Faurschou dalam Barnard, 1996) "keduanya sepakat bahwa hanya dengan munculnya kapitalisme industrilah maka lahir fashion". Merujuk pada kata fashion, maka selalu akan berkaitan dengan busana, pakaian, dandanan dan perhiasan. Di era modern ini, maraknya tren fashion membuat para perancang busana semakin berlombalomba untuk menuangkan ide kreatifnya ke dalam bentuk rancangan busana, sehingga selalu muncul mode terkini. Lestari (2014) mengatakan bahwa dengan mengenakan busana mode terkini maka terkadang sebagian orang lebih percaya diri dalam mengekspresikan dirinya. Oleh karena itu,disebutkan dalam buku pengantar fashion sebagai komunikasi (Barnard, 2011) bahwa "pakaian dipandang memiliki suatu fungsi komunikatif". Yang dimaksud sebagai fungsi komunikatif adalah bahwa pakaian yang dikenakan seseorang dapat memberikan pesan artifaktual yang bersifat nonverbal (Poerwanto \&Yudha, 2019)

Secara etimologi, 'fashion' berasal dari bahasa latin, yaitu 'factio' yang artinya membuat atau melakuan. Oleh karena itu, arti kata fashion mengacu pada kegiatan, fashion merupakan sesuatu yang dilakukan orang (Barnard, 1996:11). Fashion adalah alat komunikasi non-verbal karena seseorang dapat menilai diri kita dari cara berpakaian (Trisnawati, 2011). Dalam kata mutiara yang dituliskan Miuccia Prada mengatakan bahwa"what you wear is how you present yourself to the world, especially today, when human contacs are so quick because fashion is 


Kredo 4 (2020)
KREDO: Jurnal Ilmiah Bahasa dan Sastra
Terakreditasi Sinta 4 berdasarkan Keputusan Direktorat
Jenderal Penguatan Riset dan Pengembangan,
Kementerian Riset, Teknologi dan Pendidikan Tinggi
Republik Indonesia
Nomor: 23/E/KPT/2019. 08 Agustus 2019
https://jurnal.umk.ac.id/index.php/kredo/index

instant language”. Dalam era modern saat ini, Hasyim (2016) mengatakan bahwa fungsi fashion tidak hanya sebagai perlindungan tubuh dan memenuhi kebutuhan kesantunan, tetapi lebih dari itu menjadi suatu alat komunikasi untuk menyampaikan identitas pribadi, sosial dan budaya di suatu masyarakat.

Fashion dapat dikatakan sebagai identitas pribadi karena mencerminkan siapa diri kita, sebagai identitas sosial menunjukan suatu identitas diri di kalangan komunitas sosial atau kelompok-kelompok tertentu yang sering diekspresikan melalui dress code, sebagai identitas budaya menunjukan suatu karakter dalam kebudayaan yang biasa diekspresikan melalui kecenderungan masyarakat di suatu negara dalam berpakaian dan berpenampilan. Sehingga ahli semiotika italia Umberto Eco mengatakan "i speak through my cloth"

Fashion sebagai bentuk komunikasi non-verbal yaitu menunjukan bentuk identitas diri. Menurut Hasyim (2016) mengatakan bahwa fashion bukanlah suatu yang nyata, tetapi dapat kita ungkapkan secara nyata melalui pakaian. Dalam hal ini, pakaian yang kita kenakan membuat pernyataan tentang diri kita. Bahkan jika kita bukan tipe orang yang peduli penampilan, orang yang berinteraksi dengan kita tetap akan menafsirkan penampilan kita seolah-olah sengaja membuat suatu pesan. Sebagai contoh, jika kita Lelaki yang berpenampilan menarik, dan mengenakan kemeja atau pakaian rapi lainnya lengkap dengan parfum, orang akan memiliki penilaian pria tersebut adalah pria metroseksual. dalam hal penampilan, (prabasmoro, 2006: 400) mengatakan bahwa "cara orang berpakaian adalah persoalan bagaimana bagaimana kita mengaksersi diri sesuai dengan yang kita inginkan".

Orang-orang yang peduli penampilan akan selalu memperhatikan dalam pemilihan pakaian yang akan digunakan, mulai dari ujung rambut hingga ujung kaki. Seseorang dengan tipe tersebut beranggapan bahwa harus selalu terlihat modis dan prima di segala aktivitas yang dilakukanya. Pada pesta demokrasi pemilihan Gubernur Jakarta, telah terpilih tiga pasangan calon Gubernur diantaranya adalah: pasangan Anis Baswedan-Sandiaga Uno, AhokDjarot dan Agus-Sylvi. Dari ketiga pasangan tersebut, salah satu calon Gubernur yang menjadikan fashion sebagai alat komunikasi politik adalah Agus Harimurti Yudhoyono dengan sapaan akrabnya (AHY). AHY dianggap sebagai sosok wakil rakyat yang masih muda dan selalu berpenampilan modis hampir di setiap acara. Pada kampanye pilgub, AHY sengaja berpenampilan beda dari dua pasangan calon lainnya dengan membuat busana khusus yang diberi nama 'tacticool'. Busana tersebut sengaja dibuat untuk menunjukan identitas dirinya saat berkampanye menyapa masyarakat. Hal ini menarik untuk dibahas lebih dalam untuk melihat bagaimana fashion dapat menjadi suatu media untuk menyampaikan pesan tertentu kepada masyarakat.

Penelitian terdahulu terkait semiotik telah dilakukan oleh Aulia \& Nurhayati (2019) yang mengkaji semiotik pada meme di media sosial. Pada studi tersebut mengatakan bahwa terdapat hubungan yang erat antara tanda, objek, 


Kredo 4 (2020)
KREDO: Jurnal Ilmiah Bahasa dan Sastra
Terakreditasi Sinta 4 berdasarkan Keputusan Direktorat
Jenderal Penguatan Riset dan Pengembangan,
Kementerian Riset, Teknologi dan Pendidikan Tinggi
Republik Indonesia
Nomor: 23/E/KPT/2019. 08 Agustus 2019
https://jurnal.umk.ac.id/index.php/kredo/index

dan penafsiran. Sehingga hal tersebut sejalan dengan studi ini yang membahas tentang tanda fashion pada AHY. Selain itu, Lestari (2014) juga melakukan studi tentang fashion mahsiswa. Lestari mengatakan bahwa busana bagi mahasiswa lebih dipandang sebagai suatu cara untuk mengomunikasikan identitas mereka sebagai mahasiswa. Identitas tersebut diikuti oleh kepatuhan akan adanya regulasi aturan "moral" kolektif sebagai masyarakat "ilmiah", yang menjadikan kerapian sebagai kriteria akan suatu identitas intelektual.

Penelitian ini dibuat untuk mencari reprentasi makna fashion AHYsebagai identitas diri dan sosial dalam pilgub 2016 sebagai media komunikasi politik. Penelitian ini bertujuan untuk memberikan wawasan kepada pembaca mengenai fungsi mode yang tidak hanya digunakan untuk menutupi tubuh serta menjaga kesopanan, tetapi dapat mengarah sebagai media komunikasi dalam menunjukkan identitas diri.

\section{KAJIAN TEORI}

\section{Semiotika}

Semiotik adalah ilmu yang mengkaji tentang tanda. Menurut Ferdinand de Saussure (1996: 16) semiologi adalah sebuah ilmu umum tentang tanda,"suatu ilmu yang mengkaji kehidupan tandatanda di masyarakat" (a science that studies the life if signs within society). Sentra pemikiran Sausssure yaitu konsep dikotomi mengenai bahasa/tuturan. Preferensi Saussure secara khusus tertuju pada linguistik sinkronik. Analisis bahasa secara sinkronik adalah analisis bahasa sebagai sistem yang eksis pada suatu titik waktu tertentu yang sering kali disebut kontemporer dengan mengabaikan rute yang telah dilaluinya sehingga dapat terwujud seperti sekarang. Konsep yang dikembangkan di dalam linguistik sinkronik Saussuren berkisar pada dikotomi-dikotomi tertentu, yaitu: langue dan parole, sintagmatik dan paradigmatik, serta penanda dan petanda.

Menurut Hall dalam Trisnawati (2011) mengatakan bahwa "Sistem semiologi selalu berkaitan erat dengan implikasi dari sistem representasi. Sedangkan representasi itu sendiri adalah produksi makna melalui bahasa". Dengan Demikian, Semiotika adalah salah satu pendekatan yang dapat dijadikan sebagai sumber referensi dalam mengkaji dan menganalisa fenomena busana. berdasarkan dikotomi Saussure yang kemudian dikembangkan oleh Roland Barthes, langue and parole serta penanda dan petanda adalah dua hal utama yang menjadi landasan teori dalam penelitian ini.

Fashion adalah suatu obyek yang selalu berkaitan erat dengan citra dan gaya hidup seseorang. Dalam hal ini, Trisnawati (2011) mengatakan bahwa suatu nilai guna (use value) bukan menjadi satu-satunya hal yang ingin dicapai seseorang Ketika mengenakan selembar baju. Lebih dari itu karena seseorang lebih mengedepankan citra tertentu yang ingin dicapai dengan mengenakan suatu busana tertentu, seperti cantik, modis, trendi, anggun, elegan dan femininin. Dengan demikian, dapat dikatakan bahwa sign value dianggap jauh lebih penting daripada use value itu sendiri. Saat ini, Masyarakat, khususnya Indonesia dengan tipikal 


Kredo 4 (2020)
KREDO: Jurnal Ilmiah Bahasa dan Sastra
Terakreditasi Sinta 4 berdasarkan Keputusan Direktorat
Jenderal Penguatan Riset dan Pengembangan,
Kementerian Riset, Teknologi dan Pendidikan Tinggi
Republik Indonesia
Nomor: 23/E/KPT/2019. 08 Agustus 2019
https://jurnal.umk.ac.id/index.php/kredo/index

konsumtif telah menjadikan fashion sebagai ciri, identitas dan kepribadian dari pemakainya. Konsumerisme serta gaya hidup menjadikan prestise citra sebagai suatu kebutuhan, sedangkan kesemuan dan artifisial yang ada dibaliknya dianggap sebagai kebenaran (Piliang dalam Trisnawati,2011).

\section{Penanda dan Petanda}

Tanda adalah gabungan dari dua unsur, pertama adalah penanda suatu unsur material (signifant) yaitu bunyi tertentu dalam bahasa lisan, coretan grafis dalam bahasa tulis dan kedua adalah petanda suatu unsur mental (signifie) yaitu konsep. Kedua unsur tersebut tidak dapat dilepaskan satu sama lain. Menurut (Barthes, 1981:38-39) mengatakan bahwa hakikat penanda adalah murni sebuah relasi yang pembatasanya tidak mungkin terlepaskan dari petanda. Petanda bukan aktifitas kesadaran maupun benda nyata, tetapi ia dapat didefinisikan hanya lewat penandaan atau dengan cara sifatnya.

Petanda adalah sesuatu yang dimaksudkan oleh orang yang menggunakan tanda tersebut. Sedangkan Penanda merupakan

penghubung/mediator yang mana membutuhkan suatu materi. Dalam semiologi, penanda dipancarkan oleh materi tertentu yang disebut sebagai material dalam bentuk (bunyi, objek, citra). Pengaturan makna dari sebuah tanda memerlukan konvensi sosial di kalangan komunitas bahasa. Dalam hal ini makna suatu tanda mucul dikarenakan adanya kesepakatan diantara komunitas pengguna bahasa. Sedangkan signifié adalah gambaran mental yakni pikiran atau konsep aspek mental dari bahasa (Saussure, 1967: 98).

Sebuah tanda terdiri dari sebuah penanda (signifier) dan petanda (signified). Penanda mengacu pada petanda,yang selanjutnya mengacu pada referensi atau realitas. Dalam pandangan Saussuren, makna adalah apa-apa yang ditandakan (petanda),yaitu kandungan isi. Pada dasarnya apa yang disebut signifier dan signifier da signified tersebut adalah produk kultural. Hubungan antara keduanya bersifat arbitrer (diada-adakan) sebab tidak ada keterkaitan logis (Piliang, 2003). Saussure menekankan bahwa tidak ada hubungan yang logis antara penanda dan petanda. Jadi hubungan yang ada adalah hubungan yang arbitrer yang dibentuk dari kesepakatan sosial.

Menurut Hasyim (2016) Terdapat hubungan diadik antara penanda dan petanda dan memberikan penjelasan bahwa kedua unsur itu bertalian erat, penanda dan petanda dan reaksi mental terhadap penanda dan petanda menghubungkan satu dengan yang lain melalui aktivitas mental yang dibentuk oleh budaya dan kesepakatan. Dengan kata lain, tanda yang kita pakai ditentukan oleh kesepakatan yang mempunyai nilai kultural. Kearbitreran diilustrasikan, antara kata pohon dan sebatang pohon berarti pohon di dalam satu komunitas, maka ia akan menjadi satu konvensi, dengan pengertian ia berada tetap pada posisi yang disepakati komunitas tersebut. Saussure memberikan tekanan pada citra akustik (penanda) dan konsep (petanda) merupakan entitas yang terpisah dan yang satu menyebabkan timbulnya yang 


Kredo 4 (2020)
KREDO: Jurnal Ilmiah Bahasa dan Sastra
Terakreditasi Sinta 4 berdasarkan Keputusan Direktorat
Jenderal Penguatan Riset dan Pengembangan,
Kementerian Riset, Teknologi dan Pendidikan Tinggi
Republik Indonesia
Nomor: 23/E/KPT/2019. 08 Agustus 2019
https://jurnal.umk.ac.id/index.php/kredo/index

lain sebab kesepakatan sosial bertindak sebagai perekat yang melekatkan mereka.

\section{Langue dan Parole}

Dalam buku Kriss Budiman, Barthes mengaitkan konsep bahasa, langue dan parole dengan fashion. Menurutnya, sama halnya dengan bahasa sebagai suatu sistem (aturan sosial). Langue adalah bahasa sebagai objek sosial yang murni, keberadaanya berada di luar individu, yaitu sebagai seperangkat konvensi-konvensi sistematik yang berperan penting di dalam komunikasi. Sebagai sebuah institusi sosial, langue sama sekali bukan tindakan dan tidak bisa pula dirancang, diciptakan atau diubah secara pribadi. Parole merupakan bagian dari bahasa yang sepenuhnya individu. Parole dipandang sebagai kombinasi yang memungkinkan penutur mampu menggunakan kode bahasa untuk mengungkapkan pikiran pribadinya. Dalam hal ini, fashion sebagai langue berarti aturan sosial tentang pakaian. Misalnya model-model pakaian, dan aturan-aturan sosial sehingga sesuatu itu disebut pakaian. Sementara itu, parole adalah tindakan secara individu dalam hal berpakaian dan bentuk ekspresi individu dalam memilih dan mengenakan pakaian (Barthes, 2005: 9).

Berkaitan dengan pembedaan antara langue and parole, Roland Barthes (1981:26-27) memilah fenomena busana ke dalam tiga sistem yang berlainan. Pertama, busana yang ditulis (clothes as written about) yaitu yang dideskripsikan di dalam sebuah majalah mode atau media cetak lainya dengan sarana bahasa tulis. Kedua, busana yang difoto (clothes as photograph). Ketiga adalah busana yang dikenakan (clothes as worn) atau busana yang sesungguhnya (real clothes). Dalam pengkajian (real clothes), dapat dilihat bahwa langue busana adalah bagian-bagian pakaian serta 'detail-detailnya' yang variasinya dapat mengakibatkan perubahan makna. Sedangkan parole-nya terdiri atas segala fenomena bahan atau fabrikasi yang acak dan juga gaya berpakaian individual (seperti kebiasaan pribadi dalam berbusana atau asosiasi bagian-bagianya secara bebas).

\section{Denotasi dan Konotasi}

Dalam kajian semiotik saussure yang dikembangkan oleh Roland Barthes, membuat sebuah model sistematis dalam menganalisis makna dari tanda-tanda. Fokus Perhatian Barthes lebih tertuju pada gagasan tentang signifikasi dua tahap. Signifikasi tahap pertama merupakan hubungan antara signifier dan signified di dalam sebuah tanda terhadap realitas eksternal yang disebut sebagai denotasi (Sobur, 2012:128). Denotasi adalah makna tatanan pertama, yaitu makna harfiah sebuah kata atau citra. Makna denotasi sebuah citra, gambar, lukisan atau foto adalah citra dari citra itu sendiri. Dalam Contoh, denotasi dari kata "jas woll" seperti ditemukan pada The Cambridge Encyclopedia, maknanya tentu saja, adalah pakaian yang kasar, berat, terbuat dari wol, pakaian luar yang pertama kali dibuat di skotlandia, dan dibuat dalam beberapa model jahitan. Denotasi bersifat faktual. Denotasi diatas menunjukan bahan pembuat, tempat pembuatan, waktu pembuatan dan 


Kredo 4 (2020)
KREDO: Jurnal Ilmiah Bahasa dan Sastra
Terakreditasi Sinta 4 berdasarkan Keputusan Direktorat
Jenderal Penguatan Riset dan Pengembangan,
Kementerian Riset, Teknologi dan Pendidikan Tinggi
Republik Indonesia
Nomor: 23/E/KPT/2019. 08 Agustus 2019
https://jurnal.umk.ac.id/index.php/kredo/index

sebagainya. Dalam Kata lain, denotasi adalah jawaban atas pertanyaan "seperti apakah barang/gambar itu?'. inilah apa yang dikandung citra. Hal ini sejalan dengan apa yang dikatakan (Hasyim, 2016) bahwa Makna denotasi bersifat langsung, artinya makna khusus yang terdapat dalam suatu tanda atau gambaran dari sebuah petanda.

Sementara itu, signifikasi tahap kedua adalah konotasi yang disebut sebagai tatanan kedua penandaan atau makna. Hal ini menggambarkan interaksi yang terjadi ketika tanda bertemu dengan perasaan atau emosi dari pembaca (Sobur, 2012:1280). Konotasi dijelaskan sebagai suatu kata atau citra yang membuat orang berpikir atau merasa, atau sebagai asosiasi bahwa sebuah kata atau citra adalah untuk seseorang. Konotosi adalah fungsi sosial suatu fashion. Misalnya fashion atau pakaian untuk menunjukkan karakter seseorang, (pakaian seragam sekolah atau dress code dalam suatu komunitas, dll). Secara semiologis, fashion sebagai sistem tanda dibentuk oleh relasi antara penanda (pakaian itu sendiri) dan petanda (makna yang ditumbulkan dari pakaian itu).

Ketika kita melihat suatu komunitas bikers dengan dress code nya, maka apa yang dikenakan oleh komunitas tersebut adalah penanda (wujud pakaian) dan makna dari pakaian yang dikenakan adalah petanda, yaitu anggota komunitas bikers. Jadi, dress code yang dikenakan anggota komunitas tersebut berfungsi sebagai identitas sosial, yang bermakna pakaian seragam untuk anggota komunitas bikers. Akhirnya dapat dikemukakan bahwa denotasi dan konotasi adalah dua tingkatan makna, keduanya juga dapat dianggap sebagai dua jenis makna. Menurut (Barnard, 1996:123) mengatakan bahwa denotasi dan konotasi merupakan konsep analitis. Konotasi dan Denotasi digunakan dalam menganalisis dan menjelaskan pengalaman bukan menemukan pengalaman di dalamnya.

\section{METODE PENELITIAN}

Penelitian ini menggunakan pendekatan deskriptif kualitatif yang berlandaskan fenomena atau realita yang terjadi di lapangan. Hal ini sesuai dengan pembahasan pada penelitian ini yang akan dideskripsikan secara terperinci berdasarkan fenomena fashion sebagai strategi komunikasi. Dalam penelitian ini, data yang dianalisa adalah gambar fashion AHY selama masa kampanye 2017. Data diperoleh dari gambar yang diunggah pada akun instagram AHY. Data difokuskan pada beberapa kostum yang digunakan selama periode pencalonan hingga masa kampanye berlangsung. Banyaknya gambar yang diunggah dalam akun instagram tersebut, penulis membatasi pengambilan data hanya pada gambar fashion yang mempunyai ciri khas Indonesia/Jakarta serta busana tacticaal sebagai ciri khas AHY.

\section{HASIL DAN PEMBAHASAN}

Perkembangan fashion di era millenial kini semakin bervariasi, tidak hanya di luar negeri tetapi juga di Indonesia. Hal ini didukung oleh perkembangan dunia digital yang dapat diakses dengan mudah, sehingga mendukung para insan kreatif dalam mendapatkan inspirasi mode fashion 


Kredo 4 (2020)
KREDO: Jurnal Ilmiah Bahasa dan Sastra
Terakreditasi Sinta 4 berdasarkan Keputusan Direktorat
Jenderal Penguatan Riset dan Pengembangan,
Kementerian Riset, Teknologi dan Pendidikan Tinggi
Republik Indonesia
Nomor: 23/E/KPT/2019. 08 Agustus 2019
https://jurnal.umk.ac.id/index.php/kredo/index

terkini. Pada hakikatnya, busana atau pakaian dahulu hanya sekedar sebagai penutup dan pelindung tubuh untuk menjaga kesopanan. Seiring dengan berkembangnya zaman, fashion berkembang dan mode busana semakin variatif. Tingkat konsumtifitas masyarakat yang tinggi membuat para pelaku usaha fashion semakin semangat untuk mengeluarkan mode fashion terkini di pasaran. Fashion tidak lagi dianggap sebagai suatu hal yang sederhana, lebih dari itu telah menjadi suatu tren dan gaya hidup dalam menunjukan identitas dirinya melalu busana. Saat ini masyarakat cenderung terbiasa mengekspresikan karakter dirinya melalu gaya busana yang dikenakanya. Tak jarang orang berpikiran bahwa agar dianggap sebagai kekinian harus selalu berpenampilan keren dengan mengikuti dan mengenakan model fashion terkini.

Hal tersebut sejalan dengan suatu pernyataan yang diutarakan oleh Pharrell William dengan ungkapanya "Fashion Has to Reflect Who you are". Fashion mencerminkan tentang siapa diri kita, oleh karena itu juga dianggap sebagai kesan pertama ketika berinteraksi dengan orang. Dalam dunia politik, Fashion digunakan sebagai alat komunikasi non-verbal untuk menunjukan identitas dan citra dirinya di masyarakat. Hal ini terjadi pada Agus Harimurti Yudhoyono (AHY) dalam pemilihan Gubernur DKI Jakarta 2016. AHY adalah anak dari salah satu mantan Presiden Indonesia Susilo Bambang Yudhoyono (SBY) yang kala itu baru saja terjun di dunia politik dengan bergabung ke dalam partai Demokrat. Latar Belakang AHY adalah seorang lulusan akademi militer di tahun 2000. Istilah singkatan nama menjadi AHY mulai di sosialisasikan sejak kemunculanya dalam pencalonan Pilgub Jakarta. Singkatan nama tersebut sengaja dibuat sebagai identitas dirinya agar lebih mudah dikenal masyarakat dengan sapaan AHY.

Hal yang paling menonjol dari AHY tidak hanya dilihat dari prestasi-prestasi yang ditorehkanya selama menjalani proses akademi militerdan sebagai prajurit, tetapi juga pada busana yang dikenakan sehari-hari dan pada saat acara tertentu. AHY selalu dikenal sebagai sosok yang selalu berpenampilan prima dan rapi dalam segala acara. Hal ini dapat dikatakan bahwa fashion menjadi hal yang penting bagi AHY dalam berpenampilan yang akan menjadi suatu ciri khas dirinya. Maka tak heran jika fashion dapat dijadikan sebagai media komunikasi terutama bagi AHY yang berkecimpung di dunia politik. Hal ini dapat menimbulkan suatu penilaian di masyarakat, seperti: jika mendengar nama AHY maka tak jarang ungkapan yang terdengar adalah sosok wakil rakyat yang keren, kekinian, dan berpenampilan menarik dari ujung rambut hingga ujung kaki. Penampilan fisik yang ditunjukan AHY melalui fashion, dapat memunculkan suatu penilaian sebagai sosok yang berwibawa. Hal tersenut akan menjadi ciri khas yang melekat pada diri AHY di mata masyarakat.

Dalam masa kampanye pilgub 2016, AHY yang mencalonkan diri sebagai calon Gubernur Jakarta sengaja menyiapkan pakaian khusus yang akan dikenakan dan dijadikan sebagai media komunikasi politik saat menyapa 


Kredo 4 (2020)
KREDO: Jurnal Ilmiah Bahasa dan Sastra
Terakreditasi Sinta 4 berdasarkan Keputusan Direktorat
Jenderal Penguatan Riset dan Pengembangan,
Kementerian Riset, Teknologi dan Pendidikan Tinggi
Republik Indonesia
Nomor: 23/E/KPT/2019. 08 Agustus 2019
https://jurnal.umk.ac.id/index.php/kredo/index

masyarakat. pakaian tersebut di rancang dan di pesan secara khusus oleh AHY dengan tujuan kenyamanan saat menjalani aktivitas kampanye. dalam hal ini, mengingat ungkapan Umberto Eco bahwa 'i speak through my cloth' maka akan memunculkan makna lain yang lebih dari sekedar kenyamanan. Fashion atau pakaian yang menjadi identitas kampanye adalah kaos berwarna hitam dengan beberapa atribut simbol di dada dan lengan.

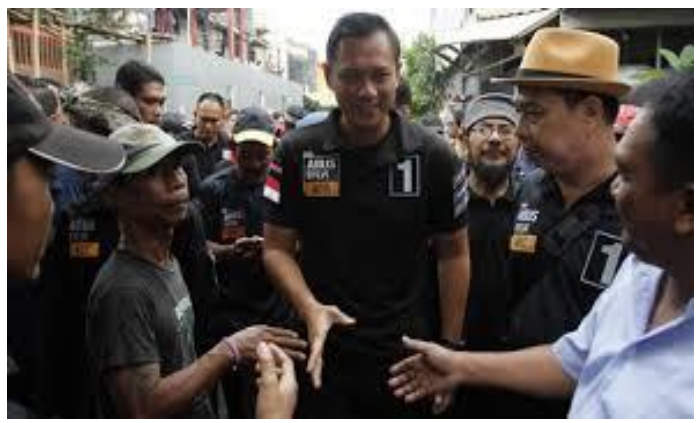

Pada gambar tersebut, Pakaian yang dikenakan AHY saat menyapa warga menjadi salah satu penekanan dalam komunikasi politik. Pakaian khusus tersebut diberi nama Tacticool. Tacticool berasal dari kata tactical, yaitu seragam yang dibuat seperti baju tactical yang biasa dipakai prajurit saat latihan atau berada di lapangan. Pada Tataran makna denotasi terlihat dalam gambar, AHY mengenakan kaos berkerah, lengan pendek, bewarna hitam dan dipadupadankan dengan celana panjang berwarna hitam. selain itu, terdapat beberapa simbol seperti : simbol bendera merah putih, angka 1, serta nama AHY. Konsep pemaknaan tersebut berada pada makna denotasi tatanan pertama, yaitu makna harfiah dari suatu citra. Makna tersebut bersifat langsung dari suatu citra, gambar, lukisan atau foto adalah citra dari citra itu sendiri.

Konsep pemaknaan kedua terletak pada tataran makna konotasi. Makna ini dikaitkan dengan konsep suatu budaya tertentu yang sudah dipahami dan diketahui oleh masyarakat kebanyakan. Pada setiap pesta demokrasi yang diwujudkan dalam pemilihan Presiden, pemilihan Gubernur maupun Ketua Daerah, maka akan ada beberapa partai koalisi yang mendukung serta berpihak pada masing-masing pasangan calon Gubernur. Seperti yang telah diketahui bahwa setiap partai mempunyai ciri khasnya dalam perbedaan warna yang juga dijadikan sebagai identitas partai tersebut. Dalam hal ini, AHY adalah calon Gubernur terpilih yang diusung oleh partai Demokrat dengan ciri khas partai berwarna biru. Sebagai calon Gubernur terpilih, tanda fashion serba hitam yang dikenakan AHY membawa konsep netral dengan tidak berpihak pada partai tertentu. Emblem bendera Merah Putih melambangkan sosok seorang yang nasionalis. Konotasi nasionalis dan netral adalah suatu tanda pada AHY yang di cerminkan melalui fashion. Bentuk-bentuk penanda melalui fashion tersebut tersebut disosialisasikan pada masyarakat dalam berbagai aktivitas politik AHY.

Pada gambar tersebut menunjukan bahwa kaos tacticaal yang dikenakan oleh AHY saat kampanye di daerah pemukiman warga terlihat lebih sederhana. Kaos dengan tipikal polo shirt menjadi salah satu busana yang dipilih untuk dikenakan saat aktivitas kampanye outdoor atau ketika mengunjungi daerah pemukiman padat penduduk di siang hari. Warna 


Kredo 4 (2020)
KREDO: Jurnal Ilmiah Bahasa dan Sastra
Terakreditasi Sinta 4 berdasarkan Keputusan Direktorat
Jenderal Penguatan Riset dan Pengembangan,
Kementerian Riset, Teknologi dan Pendidikan Tinggi
Republik Indonesia
Nomor: 23/E/KPT/2019. 08 Agustus 2019
https://jurnal.umk.ac.id/index.php/kredo/index

hitam pada kaos tersebut merupakan ciri khas yang menjadi identitas diri AHY untuk menunjukan bahwa dirinya netral sebagai seorang calon pemimpin. Walaupun fashion yang dikenakan pada gambar tersebut terlihat simpel, namun AHY tetap menunjukan komunikasi nya melalui busana yang dikenakan yang terlihat dari desain kaos tersebut. Emblem angka satu yang sengaja di cetak besar menunjukan agar masyarakat dapat melihat dengan jelas dan terus mengingat bahwa AHY adalah calon Gubernur dengan nomor urut 1 . Sedangkan emblem bertuliskan agussylvi sengaja ditempel agar terus mengkomunikasikan secara tidak langsung kepada masyarakat bahwa agus-sylvi adalah pasangan calon Gubenur dan wakil Gubenur dengan nomor urut 1. Dengan dimikian, fashion tersebut memudahkan AHY untuk menunjukan identitas diri dan mengkomunikasikan kepada masyarakat, bahwa secara tidak langsung hanya dengan melihat busana yang dikenakan membuat masyarakat selalu ingat dengan sendirinya pasangan calon gubernur nomor urut 01.

\section{Fashion Sebagai Identitas Diri}

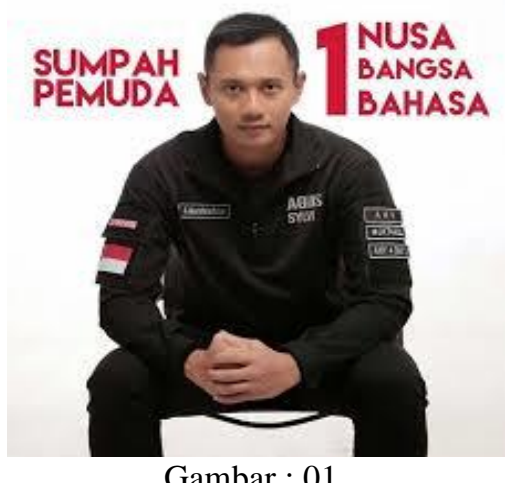

Kaos tacticaal yang dikenakan AHY menunjukan karakter dan identitas sebagai sosok calon pemimpin yang energic, tegas dan berjiwa nasionalis. Hal ini sama seperti yang dikemukakan oleh AHY dalam salah satu wawancara media "Ini untuk menyatukan energi, menyatukan identitas. Hitam tidak diasosiasikan partai mana pun. Hitam sederhana, ada hitam dan putih lebih ketegasan saja," (detik.com). Latar belakang militer yang dimiliki AHY mempengaruhi gaya busana yang ia pilih untuk identitas kampanye. Menurut Bernard (2011:86) memberikan penekanan terhadap bagaimana fashion digunakan sebagai media komunikasi dengan mengatakan bahwa melalui pakaian orang mencoba menunjukkan kelas sosial (identitas diri dan karakter). kelas sosial yang dimaksud adalah, bahwa AHY sebagai tokoh publik berusaha memberikan citra dan kesan yang baik di mata masyarakat dengan selalu memperhatikan gaya berpakaiannya. Kaus tacticaal tersebut selalu dikenakan oleh AHY hampir di seluruh aktivitas yang dijalakanya selama masa kampanye. Kaus tersebut seakan telah menjadi bagian karakter yang melekat di di AHY. Agus Harimurti Yudhoyono, salah satu bakal calon gubernur DKI Jakarta, punya trademark meski masa kampanye belum mulai. Trademark itu ialah tactical. suit yang selalu ia pakai pada berbagai kesempatan $(\mathrm{CNN}$ Indonesia.com). 


Kredo 4 (2020)
KREDO: Jurnal Ilmiah Bahasa dan Sastra
Terakreditasi Sinta 4 berdasarkan Keputusan Direktorat
Jenderal Penguatan Riset dan Pengembangan,
Kementerian Riset, Teknologi dan Pendidikan Tinggi
Republik Indonesia
Nomor: 23/E/KPT/2019. 08 Agustus 2019
https://jurnal.umk.ac.id/index.php/kredo/index

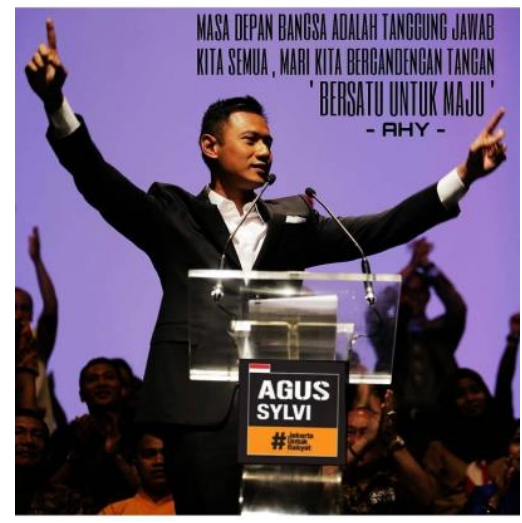

Gambar: 02

Gambar nomor 2 adalah gaya berbusana AHY yang menjadi ciri khas identitas dirinya setelah kaos tacticaal. Setelan kemeja dan jas adalah busana yang seringkali dikenakan AHY di berbagai kesempatan acara formal. Berdasarkan hasil observasi yang dilakukan melalui berbagai akun media sosial resmi milih AHY beserta keluarganya, terlihat bahwa AHY adalah salah satu tokoh politik yang peduli dengan penampilan khususnya pada gaya busana. Dalam hal ini, kemeja dan jas menjadi salah satu gaya favorit yang ia unggulkan ketika berbusana. Pada pemilihan Gubernur DKI Jakarta, jas warna hitam menjadi pilihan karena diaggap sesuai dengan konsep kampanye, yaitu bersikap netral untuk seluruh masyarakat Jakarta. Kemeja dan Jas menjadi identitas diri AHY saat membawakan pidato. Dalam hal ini, busana yang dikenakan tersebut megkomunikasikan secara tidak langsung sebagai sosok calon pemimpin yang rapi, tegas, disiplin dan memegang teguh norma dan aturan. Dengan demikian, dapat dikatakan bahwa peduli terhadap fashion menjadi hal penting untuk sesalu dijaga dan diperhatikan,

\section{karena melalui fashion dapat menunjukan citra diri seseorang.}

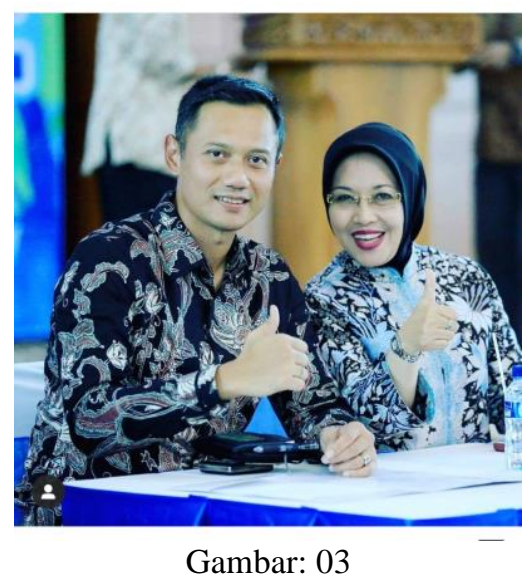

Pada gambar 03 menunjukan busana yang dikenakan AHY adalah batik dengan dominasi warna hitam. Merujuk pada konsep awal bahwa warna hitam menjadi pilihan untuk konsep busana selama masa kampanye berlangsung. Makna denotasi pada gambar tersebut adalah suatu tanda yang bersifat material, dimana AHY bersama dengan wakil menghadiri suatu acara untuk kepentingan pilgub DKI Jakarta. AHY datang dengan mengenakan ciri khas busana traditional Indonesia, yaitu batik. Sedangkan pada tataran konotasi menunjukan bahwa batik dengan dominasi warna hitam mencerminkan sikap netral dimana sesuai dengan konsep budaya Indonesia yang menganggap warna hitam mencerminkan keteguhan serta kekuatan. Hal ini sejalan dengan ideologi AHY yang menjadikan warna hitam sebagai trademark selama masa pemilihan Gubernur. Melalui batik yang ia kenakan ingin menyampaikan pesan sebagai calon pemimpin yang cinta Indonesia dan menunjukan konsistensi identitas diri. 


Kredo 4 (2020)
$\begin{gathered}\text { KREDO: Jurnal Ilmiah Bahasa dan Sastra } \\ \text { Terakreditasi Sinta } 4 \text { berdasarkan Keputusan Direktorat } \\ \text { Jenderal Penguatan Riset dan Pengembangan, } \\ \text { Kementerian Riset, Teknologi dan Pendidikan Tinggi } \\ \text { Republik Indonesia }\end{gathered}$
$\begin{gathered}\text { Nomor: 23/E/KPT/2019. 08 Agustus 2019 } \\ \text { https://jurnal.umk.ac.id/index.php/kredo/index }\end{gathered}$

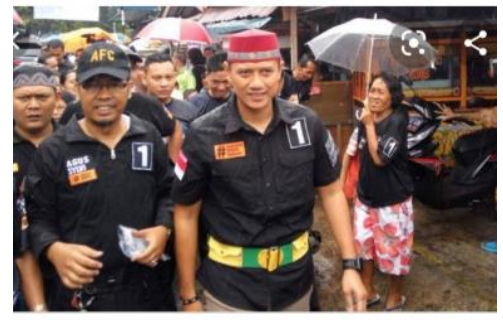

Gambar: 04

Fashion sebagai identitas diri juga ditunjukan pada gambar 04. Tataran makna denotasi menunjukan AHY yang sedang mengenakan kemeja tacticaal beserta penambahan atribut seperti peci dan sabuk. AHY melakukan kampanye untuk menyapa dan mendengarkan keluhan warga secara langsung. Di sisi lain, tataran makna konotasi terletak pada atribut yang ia kenakan agar merasa lebih dekat dengan warga jakarta. Atribut seperti peci dan sabuk yang ia kenakan merupakan atribut traditional yang mengarah pada ciri khas rakyat Jakarta khususnya budaya betawi. Desain kemeja yang dibuat oleh para pengusung AHY selalu menekankan pada desain emblem angka 1 dan bendera Indonesia (merah-putih). Emblem angka 1 menjadi poin utama yang selalu ada pada berbagai macam bentuk kostum tacticaal yang telah dibuat, seperti kemeja, polo shirt, kaos lengan panjang dan lain sebagainya. Hal tersebut sangatlah penting untuk menunjukan identitas diri AHY sebagai calon Gubernur DKI Jakarta dengan nomor urut 1, dengan demikian pesan yang disampaikan kepada masyarakat, agar selalu ingat kandidat dengan nomor urut 1 hingga masa pencoblosan nanti. Sedangkan emblem bendera untuk memberikan pesan bahwa AHY adalah INDONESIA, siap untuk membangun negeri lebih baik khususnya kota jakarta. Sementara emblem berwarna orange bertuliskan \#Jakartauntukrakyat merupakan desain slogan yang sengaja dibuat untuk mengkampanyekan AHY siap memimpin Jakarta. Simbol \# dibuat agar slogan tersebut dapat digunakan untuk kegiatan kampanya melalui media sosail seperti tweeter, facebook dan instagram. Dengan adanya \# tersebut akan memudahkan masyarakat dalam mencari dan menggaungkan berita tentang AHY sebagai calon pemimpin DKI Jakarta

\section{Fashion Sebagai Identitas Sosial}

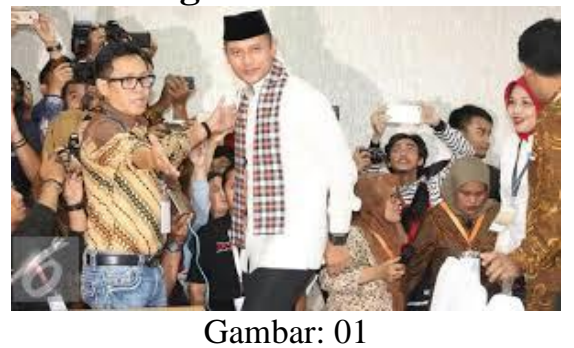

Dalam kesempatan lain, AHY terlihat mengenakan kemeja putih dipadupadankan dengan celana hitam dan sarung motif kotak-kotak dikalungkan di lehernya. Makna Denotasi pada gambar tersebut adalah suatu tanda yang bersifat material yaitu, AHY hadir di suatu acara pertemuan tim sukses kampanye dengan mengenakan pakaian dan atributnya. Tataran konotasi terletak pada konsep kultural yaitu identik dengan khas busana budaya betawi (budaya traditional Jakarta). Sebagai calon gubernur jakarta AHY menjadikan atribut sarung dalam penampilanya sebagai media komunikasi untuk menunjukan bahwa dirinya adalah 


Kredo 4 (2020)
$\begin{gathered}\text { KREDO: Jurnal Ilmiah Bahasa dan Sastra } \\ \text { Terakreditasi Sinta } 4 \text { berdasarkan Keputusan Direktorat } \\ \text { Jenderal Penguatan Riset dan Pengembangan, } \\ \text { Kementerian Riset, Teknologi dan Pendidikan Tinggi } \\ \text { Republik Indonesia } \\ \text { Nomor: 23/E/KPT/2019. 08 Agustus 2019 } \\ \text { https://jurnal.umk.ac.id/index.php/kredo/index }\end{gathered}$

bagian dari kota Jakarta yang siap menjunjung kebudayaan betawi serta siap memimipin Jakarta.

Pemaknaan pada tataran konotasi dapat menghasilkan makna yang berbeda-beda pada setiap orang dengan objek yang sama. Hal ini didasari oleh perbedaan pemikiran, budaya, sosial hingga gender. AHY tampil sebagai sosok calon Gubernur dengan membawa konsep ideologi berjiwa nasionalis, netral dan siap memimpin rakyat jakarta. Makna yang ingin di capai pada fashion AHY adalah sebagai identitas dirinya menjadi suatu identitas sosial.



Gambar: 02

Pada gambar nomor 2, AHY dan pasanganya memilih busana batik berwarna biru dipadankan dengan celana hitam. Makna denotasi dalam gambar tersebut merupakan suatu tanda yang bersifat material, yaitu AHY menghadiri peresmian penetapan para calon dan wakil Gubernur DKI Jakarta dengan mengenakan batik bermotif ondel-ondel yang menjadi ciri khas kota Jakarta. Sedangkan pemaparan makna konotasi terletak pada konsep kultural, yaitu tipikal batik yang dikenakan AHY

228 | Jurnal Kredo

Vol. 4 No. 1 Oktober 2020 sengaja di desain dengan salah satu ciri khas budaya betawi. Batik adalah salah busana traditional Indonesia dengan berbagai jenis desain motif yang biasanya inspirasi motif tersebut berasal dari daerah seperti jawa timur atau jawa tengah. Pada gambar 02 terlihat jelas bahwa AHY yang dicalonkan sebagai Gubernur Jakarta menjadikan batik yang dikenakanya sebagai media komunikasi untuk menunjukan kecintaan nya kepada masyarakat terhadap budaya betawi. Ondel-ondel merupakan tipikal boneka besar yang sangat identik dengan kota Jakarta. Dengan batik tersebut, AHY mengkomunikasikan bahwa dirinya adalah dekat dengan rakyat Jakarta, menjadi bagian dari kota Jakarta serta akan selalu mendukung kebudayaan betawi. Makna yang ingin dicapai pada batik AHY adalah bahwa identitas dirinya telah menjadi suatu identitas sosial yang lebih besar, khususnya masyarakat DKI Jakarta.

Dalam politik, fashion menjadi salah satu hal penting yang harus diperhatikan. Sebagai tokoh masyarakat terutama bagi yang mencalonkon sebagai Gubernur maka akan ada banyak mata yang menyoroti segala kegiatan dan aktifitas yang dilakukan. Dalam hal ini, fashion menjadi hal utama yang paling mudah untuk dikritisi, karena ketika seseorang mempublikasikan dirinya dan kemudian dikenal banyak orang, maka penampilan menjadi kesan pertama pada penilaian identitas dan karakter orang tersebut. Tidak terpilihnya AHY sebagai Gubernur Jakarta tidak dikarenakan atas kegagalan fashion yang dipilihnya yaitu busana tacticaal. 


Kredo 4 (2020)
$\begin{gathered}\text { KREDO: Jurnal Ilmiah Bahasa dan Sastra } \\ \text { Terakreditasi Sinta } 4 \text { berdasarkan Keputusan Direktorat } \\ \text { Jenderal Penguatan Riset dan Pengembangan, } \\ \text { Kementerian Riset, Teknologi dan Pendidikan Tinggi } \\ \text { Republik Indonesia }\end{gathered}$
$\begin{gathered}\text { Nomor: 23/E/KPT/2019. 08 Agustus 2019 } \\ \text { https://jurnal.umk.ac.id/index.php/kredo/index }\end{gathered}$

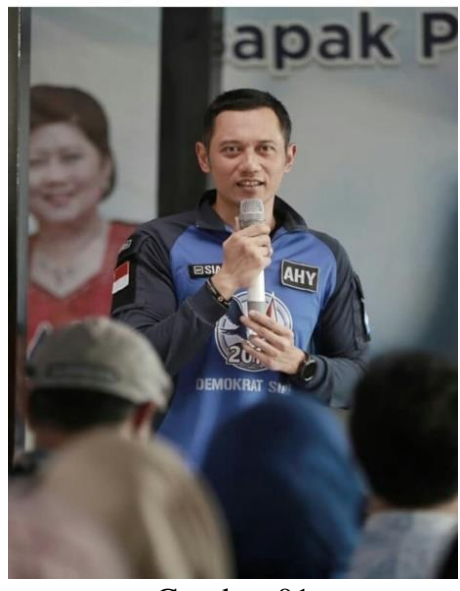

Gambar:01

Berakhirnya pesta demokrasi dengan tidak terpilihnya AHY sebagai Gubernur Jakarta, tidak menyurutkan semangatnya untuk tetap terus mempromosikan dirinya dan meningkatkan kualitas kinerja di bidang politik. Busana tacticaal yang telah menjadi ciri khasnya tetap terus digunakan dalam kegiatan politik bersama dengan partai demokrat. Berbeda pada saat Kampanye calon Gubernur Jakarta, pada gambar tersebut AHY sedikit merubah model pakaian dengan memberikan nuansa kombinasi warna biru dengan simbol partai Demokrat di bagian dada, menandakan bahwa AHY menunjukan identitas sosial dengan mengusung nama besar partai yang menaunginya.

Kegagalan AHY pada pilgub Jakarta 2016 tidak sama sekali menyurutkan jiwa nasionalis dalam membangun negeri lebih baik. Konsistensi nasionalis dan siap memimpin melalui media komunikasi fashion tetap dilanjutkan dalam berbagai aktifitas politik dalam partai yang dijalakanya. Terlihat pada gambar bahwa AHY menambahkan emblem bertuliskan kata 'siap'. Dalam aktivitas rutin politik seperti kunjungan ke berbagai kota, kegiatan sosial dan melakukan aktivitas bersama warga, AHY tetap berkomunikasi dengan rakyat dengan konsep nasionalis melalui fashion kaus tacticaal.



Gambar: 02

Pada gambar 02 menunjukan sedikit kesamaan pada tema berbusana AHY, yaitu casual. Komunikasi melalui busana tidak hanya diwujudkan melalui kaos tacticaal, tetapi juga melalui gaya busana lain, seperti jaket. Kembalinya AHY ke partai yang menaunginya, yaitu demokrat sangat terlihat jelas melalui berbagai busana yang ia kenakan dimana selalu di dominasi oleh warna biru. Berbeda dengan jaket yang dikenakan oleh para staff nya dimana hanya terdapat emblem angka 14 di bagian dada yang melambangkan nomor urut partai demokrat. Sedangkan pada desain jaket AHY dibuat berbeda dengan terdapat penambahan emblem bertuliskan A.H.Y dimana singkatan nama AHY telah menjadi identitas dirinya agar memudahkan dalam penyebutan nama yang teleh melekat di seluruh kalangan Indonesia. 


Kredo 4 (2020)
$\begin{gathered}\text { KREDO: Jurnal Ilmiah Bahasa dan Sastra } \\ \text { Terakreditasi Sinta } 4 \text { berdasarkan Keputusan Direktorat } \\ \text { Jenderal Penguatan Riset dan Pengembangan, } \\ \text { Kementerian Riset, Teknologi dan Pendidikan Tinggi } \\ \text { Republik Indonesia }\end{gathered}$
$\begin{gathered}\text { Nomor: 23/E/KPT/2019. 08 Agustus 2019 } \\ \text { https://jurnal.umk.ac.id/index.php/kredo/index }\end{gathered}$

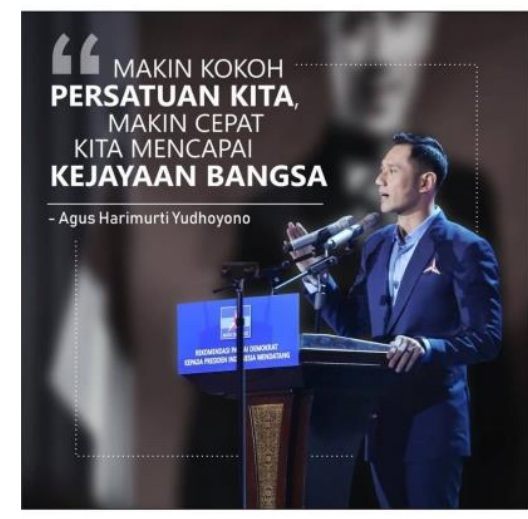

Gambar: 03

Gambar 03 menunjukan perbedaan gaya busana yang siginifikan dari yang pernah dikenakan pada saat pemilihan Gubernur DKI Jakarta. Pada gambar tersebut kemaja dan jas yang dikenakan di dominasi oleh warna biru yang melambangkan warna partai demokrat. Gaya tersebut juga didukung dengan lambang partai demokrat yang disematkan pada jasnya. Berbeda dengan gaya busana yang dikenakan pada saat meberikan pidato di masa kampanye, dimana AHY lebih memilih mengenakan setelan jas berwarna hitam agar terlihat netral di pandangan masyarakat. Dalam hal ini, dapat dikatakan bahwa fashion merupakan salah satu komponen penting yang digunakan oleh AHY dalam berpolitik. Terlihat perbedaan gaya busana di antara dua momen, yaitu momen saat pemilihan Gubernur (pilgub) dengan warna hitam yang menjadi ciri khas identitas dirinya dan ketika pilgub telah usai dengan tipikal warna biru yang menjadi identitas atas kembalinya AHY berpolitik di partai demokrat. Fashion merupakan hal yang lekat dengan citra dan gaya hidup.
Trisnawati (2011) mengatakan bahwa ketika orang mengenakan selembar baju bukan semata-semata karena nilai guna (use value). Akan tetapi lebih karena adanya nilai atau citra tertentu yang ingin dicapai dengan mengenakan busana tersebut.

Seiring dengan berkembanganya zaman, dapat dilihat bahwa dunia fashion tidak dapat terelakan lagi. Hal ini juga didukung oleh semakin berkembangnya kreatifitas anak muda dalam menciptkan desain fashion yang unik, trendi serta kekinian. Busana/pakaian tidak lagi dipandang sebagai suatu hal yang biasa. lebih dari itu bahwa fashion saat ini telah menjadi hal yang sangat penting untuk menunjukan citra diri masing-masing individu. Hal tersebut terbukti bahwa saat ini banyak sekali pengusaha muda yang memulai bisnis dengan membuat suatu clothing store maupun butik, mulai dari gaya casual yang biasa diminati anak muda hinggal gaya glamour yang biasa diminati oleh masyarakat menengah keatas. Semakin maraknya dunia online dan media sosial seperti instagram, facebook, tiktok, tweeter membuat masyarakat khususnya generasi muda yang biasa desibut kaum millenial semakin memperhatikan gaya penampilan mereka dan berlomba-lomba untuk menunjukan citra diri agar dipandang modis dan trendi di mata warga net. Dengan demikian Lestari (2014) mengatakan bahwa fashion adalah komunikasi nonverbal dengan proses penyampaian pesan menggunakan simbol-simbol, tidak dengan kata-kata langsung-percakapan. Komunikasi 


Kredo 4 (2020)
KREDO: Jurnal Ilmiah Bahasa dan Sastra
Terakreditasi Sinta 4 berdasarkan Keputusan Direktorat
Jenderal Penguatan Riset dan Pengembangan,
Kementerian Riset, Teknologi dan Pendidikan Tinggi
Republik Indonesia
Nomor: 23/E/KPT/2019. 08 Agustus 2019
https://jurnal.umk.ac.id/index.php/kredo/index

nonverbal berfungsi untuk menyampaikan sikap, perasaan dan emosi. Media sosial juga memberikan kontribusi terbesar dalam kemajuan fashion saat ini yang semakin modern dan dengan demikian fungsi fashion sebagai salah satu alat komunikasi juga semakin kuat.

Tren fashion tidak hanya terjadi di kalangan millenial, artis, maupun influencer. Saat ini, tren tersebut juga merajai dunia politik. Salah satu faktor yang mempengaruhi hal ini adalah tren para selebriti yang beralih merambah dunia politik, yang mana mereka menjabat sebagai anggota DPR atau anggota dari partai politik tertentu. Cara seseorang berpakaian dapat mencerminkan identitas dirinya. Saat ini, fashion juga menjadi sorotan masyarakat dalam berpolitik, Khususnya para partai politik yang identik dengan pemilihan warna sebagai identitas diri. Seperti PDI dengan warna merah, Golkar::kuning, Demokrat;biru dan masih banyak lagi. Hal serupa terjadi AHY yang menjadi fokus pada studi ini. Biru dan hitam merupakan warna yang lekat sekali dengan AHY. Perbedaan yang paling signifikan pada fashion AHY terlihat dari pemilihan warna busana yang ia kenakan saat mencalonkan sebagai Gubernur DKI dan saat kembalinya ke partai Demokrat. Hitam menjadi kesepakatan warna pilihan yang ia unggulkan saat masa pesta demokrasi, dimana dari busana yang ia kenanakan, AHY ingin menyampaikan suatu pesan netral sebagai calon pemimpin yang tidak berpihak pada partai tertentu. Hal tersebut juga terihati dari slogan yang digaungkan di masyarakat "AHY for all". Di sisi lain, warna biru menjadi warna yang sangat diunggulkan ketika berakhirnya pesta demokrasi. Warna biru menjadi warna kebanggaan partai Demokrat, sehingga gaya berpakaian AHY pun ikut bergeser. Terlihat di beberapa kesempatan acara, fashion AHY selalu di domiansi warna biru. Hal tersebut sengaja dibuat untuk menunjukan suatu identitas sosial di seluruh kalangan anggota partai dan masyarakat yang lebih luas bahwa biru adalah Demokrat.

\section{SIMPULAN}

Indonesia merupakan salah satu negara dengan tipikal masyarakat konsumtif. Salah satu hal yang sangat digemari adalah dunia fashion, dimana masyarakat selalu mengikuti tren fashion terkini. Hal tersebut mengakibatkan daya beli yang terus meningkat karena tipikal masyarakat yang selalu ingin membeli peluncuran desain terbaru. Fashion bukan lagi menjadi suatu hal yang biasa di mata masyarakat dimana umumnya seseorang membutuhkan pakaian untuk sekedar menutupi tubuhnya. Di zaman yang semakin maju ini, pandangan masyarakat terhadap fashion telah berubah. Saat ini fashion memiliki berbagai macam fungsi yang dapat digunakan sebagai alat komunikasi untuk menunjukan identitas diri maupun sosial yang lebih besar. Berkembangnya dunia digital, khususnya media sosial juga merupakam salah satu faktor pendukung bertambahnya fungsi fashion. Hal yang paling menarik adalah bahwa fashion merupakan alat komunikasi non-verbal yang dapat mengatakan citra seseorang dari gaya fashion yang dekenakan. Sehingga hal 


Kredo 4 (2020)
KREDO: Jurnal Ilmiah Bahasa dan Sastra
Terakreditasi Sinta 4 berdasarkan Keputusan Direktorat
Jenderal Penguatan Riset dan Pengembangan,
Kementerian Riset, Teknologi dan Pendidikan Tinggi
Republik Indonesia
Nomor: 23/E/KPT/2019. 08 Agustus 2019
https://jurnal.umk.ac.id/index.php/kredo/index

tersebut juga dibawa ke dalam dunia politik yang tercermin dalam busana tacticaal AHY.

Kaus tacticaal sebagai fashion AHY digunakan untuk menunujukan identitas, karakter dan juga nilai sosial sebagai sosok calon pemimpin yang berjiwa nasionalis dan siap memimpin negeri. Kaus tacticaal telah menjadi ciri khas AHY (trademark) di dunia politik hingga saat ini walaupun tidak terpilih menjadi Gubernur Jakarta. AHY memberikan model kaus tacticaal yang berberda pada saat masa kampanye pilgub dan saat setelah pilgub usai. Dalam proses penandaan atau pemaknaan fashion AHY (kaus tacticaal berwarna hitam) orang kerap membuat penilaian terhadap nilai sosial berdasarkan atas apa yang dipakai oleh orang tersebut. pemaknaan atas fashion
AHY yang mengkonotasikan nasionalisme dan netral muncul dari interaksi sosial yang saling dipertukarkan setiap orang, yang akan mengantarakan kepada "konsep diri" seseorang dan kelompok/komunitas dan sosialisasinya kepada keseluruan kelompok sosial yang lebih besar, yaitu masyarakat. Sementara pada pemaknaan kaus tacticaal dengan kombinasi warna biru mengkonotasikan kembalinya AHY ke partai yang dinaunginya, yaitu partai Demokrat, dengan tetap mengusung nasionalisme dan bekerja kersa. Fashion kaus tacticaal AHY tidak hanya dibuat sebagai suatu identitas dirinya tetapi telah menjadi identitas sosial masyarakat Indonesia yang melahirkan suatu makna bahwa fashion AHY sebagai simbol dari wakil rakyat tegas, mengayomi, bekerja keras dan siap memimpin.

\section{DAFTAR PUSTAKA}

Aulia, S.W \& Nurhayati. 2019. Makna Sosial Meme \#SAVETIANGLISTRIK: Analisis Semiotik. Jurnal Kredo. Vol. 3 No. 1.

Aini, Q., Rahardjo, T. \& Lestari, S.B. 2013. "Memahami Penerimaan Pembaca Fashion Blog Hijabers (pengguna Hijab Modern) Terhadap Pergeseran Makna penggunaan Hijab (Analisis Resepsi Terhadap Blog Dian pelangi)" Interaksi Online, Vol.1, No.4.

Angelina, M.S \& Triputra, P. 2015. Analisis Semiotik Fashion Ines Ariani Sebagai Bentuk Presentasi Diri. Jurnal Komunikasi. Vol. 7, No. 2, 165 - 179.

Barnard, Malcon. 2011. Fashion sebagai Komunikasi. Yogyakarta: Jalasutra.

Berek, D. 2014. Fashion Sebagai Komunikasi Identitas Sub Budaya (Kajian Fenomenologis Terhadap Komunitas Street Punk Semarang).Interaksi: Jurnal Ilmu Komunikasi. Vol.3, No.1, PP.56-66.

Budiman, Kriss. 2011. Semiotika Visual. Yogyakarta: Jalasutra. 


Kredo 4 (2020)
KREDO: Jurnal Ilmiah Bahasa dan Sastra
Terakreditasi Sinta 4 berdasarkan Keputusan Direktorat
Jenderal Penguatan Riset dan Pengembangan,
Kementerian Riset, Teknologi dan Pendidikan Tinggi
Republik Indonesia
Nomor: 23/E/KPT/2019. 08 Agustus 2019
https://jurnal.umk.ac.id/index.php/kredo/index

Barthes, Roland. 2012. Elemen-Elemen Semiologi. Yogyakarta: Jalasutra.

Hasyim, M. 2016. Fashion Sebagai Komunikasi: Analisis Semiotis Atas Fashion JOKOWI Pada Pemilihan Presidan 2014.

Hoed, Benny. 2011. Semiotika \& Dinamika Sosial Budaya. Depok: Komunitas Bambu.

Hendriyanto, Agus. 2013. Filsafat Bahasa. Surakarta: Yuma Pustaka.

Lestari, S.B. 2014. Fashion sebagai Komunikasi Identitas Sosial di Kalangan Mahasiswa. Jurnal Pengembangan Humaniora Vol. 14 No. 3.

Trisnawati, T.Y. 2011. Fashion sebagai Bentuk Ekspresi Diri dalam Komunikasi. The messanger, Vol 3.No1.

Prabasmoro, Priyana. 2006. Kajian Budaya Feminis. Yogyakarta: Jalasutra.

Rusmana, Dadan. 2014. Filsafat Semiotika. Bandung: Pustaka Setia.

Sobur, Alex. 2012. Analisis Teks Media. Bandung: PT Remaja Rosdakarya.

Yudha, R.P. \& Poerwanto. 2019. Persepsi Generasi Millineal terhadap Jilbab sebagai Identitas, Fesyen, Komunikasi Nonverbal dan Kreativitas. Journal of Tourism and Creativity. Vol.3 No. 